\title{
PENDAMPINGAN PRAKTIKUM IPA KELOMPOK SISWA BELAJAR LURING BERBASIS SIMPLE EXPERIMENT TOOLS
}

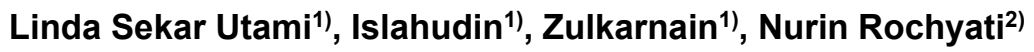 \\ 1)Pendidikan Fisika, FKIP, Universitas Muhammadiyah Mataram, Mataram, NTB, Indonesia \\ 2)Pendidikan Geografi, FKIP, Universitas Muhammadiyah Mataram, Mataram, NTB, Indonesia \\ Corresponding author : Linda Sekar Utami \\ E-mail : lindasekarutami@gmail.com
}

Diterima 30 November 2021, Direvisi 03 Desember 2021, Disetujui 03 Desember 2021

\begin{abstract}
ABSTRAK
Pengabdian ini dilaksanakan untuk menyelesaikan masalah yang dihadapi oleh Kelompok siswa yang belajar secara Luring bukan di area sekolah melainkan di Desa-desa asal siswa. Siswa merupakan objek dalam PKM ini karena merupakan mitra yang membutuhkan penanganan khusus. Adapun permasalahan yang kami temukan setelah melakukan interview dan wawancara yakni (1) Siswa merasa kesulitan melaksanakan praktikum karena alat-alat berada di laboratorium sekolah, (2) Siswa merasa kesulitan dalam meresapi atau memahami materi-materi IPA tanpa dilakukan praktikum (3) Belum mengetahui informasi tentang praktikum berbasis Simple Experiment Tools. Tim Pengabdian menawarkan solusi berupa (1) Memberikan pendampingan kepada kelompok siswa cara melakukan praktikum berbasis Simple Experiment Tools. (2) Memberi praktik dengan modul praktikum berbasis Simple Experiment Tools. Metode yang dilakukan yaitu 1) Pra Lapangan; 2) Pelaksanaan PKM; 3) Evaluasi Pasca Pendampingan. Masing-masing item terdiri dari beberapa tahapan. Setelah melakukan pendampingan, siswa dapat melakukan praktikum berbasis Simple Experiment Tools. Dari hasil evaluasi yang dilakukan diperoleh $89 \%$ siswa dapat melakukan praktikum. $100 \%$ siswa sangat suka dengan praktikum IPA yang dilakukan.
\end{abstract}

Kata kunci: praktikum IPA; belajar luring; simple experiment tools.

\begin{abstract}
This service is carried out to solve the problems faced by students who study offline, not in the school area but in the villages where the students come from. Students are objects in this PKM because they are partners who need special handling. As for the problems that we found after conducting interviews and interviews, namely (1) Students find it challenging to carry out practicum because the tools are in the school laboratory, (2) Students find it difficult to absorb or understand science materials without doing practicum (3) Do not know information about the Simple Experiment Tools-based practicum. The Devotion Team offers solutions in the form of (1) Assisting groups of students on how to do practicals based on Simple Experiment Tools. (2) Provide practice with a practicum module based on Simple Experiment Tools. The methods used are 1) Pre-Field; 2) Implementation of PKM; 3) Evaluation of Post Mentoring. Each item consists of several stages. After assisting, students can do practical work based on Simple Experiment Tools. From the evaluation results carried out, it was found that $89 \%$ of students were able to do the practicum. $100 \%$ of students like the science practicum carried out.
\end{abstract}

Keywords: science practicum; offline learning; simple experiment tools.

\section{PENDAHULUAN}

Mitra dalam pengabdian ini adalah siswa kelompok luring Desa Gontoran yang bersekolah di SMP maupun MTs disekitar Kecamatan Lingsar. Istilah belajar luring muncul akibat dari adanya pandemic covid-19. Terdapat dua jenis pembelajaran yang dilaksanakan antara lain daring (dalam jaringan) dan luring (luar jaringan). Untuk daerah-daerah dengan situasi ekonomi dan sinyal kurang akan menerapkan luring dengan tetap menerapkan prokes yang surat ijinnya dikeluarkan oleh dinas pendidikan suatu daerah tergantung dari zona iklim covid-19 yang berlaku. Mulai dari level 1 sampai dengan level 4. Untuk daerah dengan kondisi siswa tidak memiliki gawai secara merata akan menerapkan luring kelompok belajar di masingmasing dusun asal siswa. Desa Gontoran salah satu desa yang terletak di Lombok barat dengan level 3 sehingga beberapa sekolah boleh luring dengan syarat melakukan pembelajaran kelompok di rumah masingmasing siswa dengan maksimal 5 orang siswa. 
Dua tahun ini, pembelajaran banyak dilakukan dari rumah. Ada yang menerapkan Luring ada juga yang menerapkan Daring. Bagi sekolah-sekolah yang letaknya jauh dari hiruk pikuk kota, sangat sulit menerapkan Daring,karenanya gurumembuat pembelajaran secara Luring maupun tatap muka terbatas di rumah-rumah siswa dengan mengikuti protokol kesehatan.

Berdasarkan hasil interview kepada Kelompok Siswa pada tanggal 15 Agustus 2021 diperoleh informasi bahwa secara garis besar permasalahan dalam pembelajaran daring maupun luring adalah (1) Siswa merasa kesulitan melaksanakan praktikum karena alatalat berada di laboratorium sekolah, (2) Siswa merasa kesulitan dalam meresapi atau memahami materi-materi IPA tanpa dilakukan praktikum (3) Belum mengetahui informasi tentang praktikum berbasis Simple Experiment Tools.

Media pengajaran sangat penting sebab media adalah alat bantu mentranfer ilmu untuk meningkatkan hasil belajar yang dicapai. Alasan media pembelajaran dapat meningkatkan hasil belajar antara lain:

1. Pengajaran akan lebih menarik perhatian siswa sehingga dapat menumbuhkan motivasi belajar.

2. Bahan pengajaran akan lebih jelas maknanya sehingga dapat lebih dipahami oleh para siswa, dan memungkinkan siswa menguasai tujuan pengajaran lebih baik.

3. Metode mengajar akan lebih bervariasi, tidak semata-mata komunikasi verbal melalui penuturan kata-kata oleh guru, sehingga siswa tidak bosan dan guru tidak kehabisan tenaga, apalagi bila guru mengajar untuk setiap jam pelajaran.

4. Siswa lebih banyak melakukan kegiatan belajar, sebab tidak hanya mendengarkan uraian guru, tetapi juga aktivitas lain seperti mengamati, melakukan, mendemonstrasikan dan lain-lain.

Dalam pembelajaran fisika, media adalah bagian penting sebagai penunjang motivasi dan peningkatan hasil belajar. Beberapa contoh media pembelajaran fisika antara lain:

1. Jangka Sorong. Jangka sorong digunakan untuk mengukur deminsi luar atau deminsi dalam suatu benda.

2. Mesin hidrolik. Mesin ini biasa kita temukan di bengkel mobil atau tempat pencucian mobil fungsinya untuk mengangkat mobil.

3. Alat Ukur di dapur seperti gelas ukur dan lain-lain untuk menentukan massa jenis benda sekitar seperti batu, kayu, besi, dll.

Media pembelajaran fisika sangat beragam, seperti contoh di atas. media tersebut diperoleh dengan membeli atau membuat sendiri. Kalau membeli tentu biayanya sangat mahal sedangkan membuat sendiri, biaya menjadi terjangkau yaitu dengan barang-barang bekas atau jenis lainnya.

Berdasarkan Latar belakang tersebut dapat ditawarkan solusi dengan melakukan praktikum menggunakan Simple Experiment Tools. Dimana bahan dan alat ada di lingkunan sekitar. Kelompok Siswa SMP Desa Gontoran terdiri dari 2 Kelompok dikarenakan berasal dari dua sekolah berbeda yaitu SMPN 1 Lingsar dan SMPN 2 Lingsar. Siswa SMP Desa Gontoran tersebar dari kelas VII sampai dengan Kelas IX. Karena 2 tahun berjalan pembelajaran secara online dan luring sehingga praktikum jarang dilakukan. Fasilitas yang digunakan sesuai dengan kondisi lingkungan siswa, jauh dari Laboratorium. Ada yang belajar di Saung, ada juga di teras-teras rumah salah satu siswa. Guru-guru mereka datang silih berganti sesuai jadwal. Guru IPA hanya datang dua kali dalam sebulan.
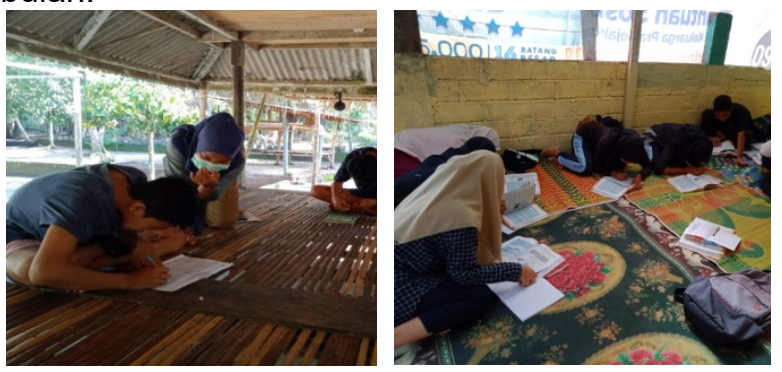

Gambar 1. Kelompok Belajar Luring Desa Gontoran.

Berdasarkan hasil observasi dan interview pada tanggal 15 Agustus 2021 diperoleh informasi tentang beberapa permasalahan yang terjadi, yakni:

1. Guru merasa kesulitan melaksanakan praktikum

2. Praktikum yang biasanya dilakukan di laboratorium tidak pernah dilakukan karena terkendala peralatan yang harus dibawa ke luar laboratorium, karena guru hanya memberikan teori melalui gambar di buku paket.

3. Siswa merasa kesulitan dalam meresapi materi-materi IPA tanpa melakukan praktikum.

Materi IPA tanpa melakukan praktikum rasanya kurang mengena dan nyata, karena dalam mempelajari IPA harus disertakan dengan praktikum. Praktikum dapat dilakukan dengan cara virtual maupun langsung.

4. Belum mengetahui informasi tentang praktikum Berbasis Simple Experiment Tools 
Setidaknya pengembangan pembelajaran terutama praktikum dapat dilakukan meskipun tanpa laboratorium. Guru-guru IPA khususnya yang berada di 3T harus sigap melakukan praktikum meski dalam keadaan terbatas alat dan bahan dengan memanfaatkan benda disekitar kita. Simple Experiment Tools dapat membantu Guru dalam melakukan praktikum karena dapat dibawa dari rumah dan mudah diperoleh.

Adapun solusi yang ditawarkan sebagai berikut:

1. Memberikan pendampingan kepada Kelompok Siswa Belajar Luring di desa Gontoran dengan melakukan praktikum berbasis Simple Experiment Tools.

2. Memberi praktik dengan modul praktikum berbasis Simple Experiment Tools.

\section{METODE}

Adapun metode yang dilakukan dalam pengabdian ini adalah:

\section{Pra Lapangan}

Pada tahap ini, tim PKM akan melakukan kegiatan yakni: Melakukan koordinasi dengan Kelompok Siswa Belajar Luring Desa Gontoran, Menyiapkan modul praktikum Simple Experiment Tools sebagai pegangan siswa, Melakukan packing Acara praktikum Simple Experiment Tools.

\section{Pelaksanaan PKM}

Kegiatan yang dilakukan adalah: Melakukan Pendampingan Praktikum Berbasis Simple Eksperiment Tools, Melakukan monitoring dan controlling untuk melihat dampak positif Pendampingan praktikum berbasis Simple Experiment Tools.

\section{Pasca Workshop (Evaluasi PKM)}

Tim PKM melakukan evaluasi terhadap kemampuan siswa dalam melakukan praktikum berbasis Simple Experiment Tools. Di samping itu, tim PKM juga melakukan evaluasi respon siswa terhadap kegiatan praktikum yang sudah dilakukan baik terhadap tingkat emosi siswa maupun peningkatan pemahaman siswa terhadap materi pada jenjang masing-masing.

\section{Iptek Bagi Masyarakat.}

Adapun IPTEK yang diberikan kepada mitra sebagai berikut:

1. Meningkatkan kemampuan dan keterampilan berupa Praktikum IPA berbasis Simple Experiment Tools.

2. Memberikan Pendampingan Praktikum berbasis Simple Experiment Tools di masa pandemi covid-2019.

3. Melakukan kontrol terhadap kegiatan belajar siswa baik di sekolah maupun di luar sekolah melalui penyebaran media pembelajaran dalam kegiatan praktikum berbasis Simple Experiment Tools.

\section{Partisipasi Mitra}

1. Mitra (Siswa) menyiapkan peralatan yang dibutuhkan.

2. Mitra berperan aktif dalam pengembangan lembaga yang ditunjukkan dalam kekompakkan dalam membangun komunikasi yang baik antar anggota.

\section{HASIL DAN PEMBAHASAN \\ Pembuatan Modul Praktikum}

Modul yang dibuat adalah modul praktikum yang berhubungan dengan alat-alat sederhana yang dapat diperoleh dari dapur atau lingkungan sekitar. Modul terdiri dari beberapa acara yang memuat materi-maeri IPA SMP. Modul tersebut digunakan oleh siswa dalam melakukan praktikum baik pada saat luring atau mencoba sendri di rumah masingmasing.

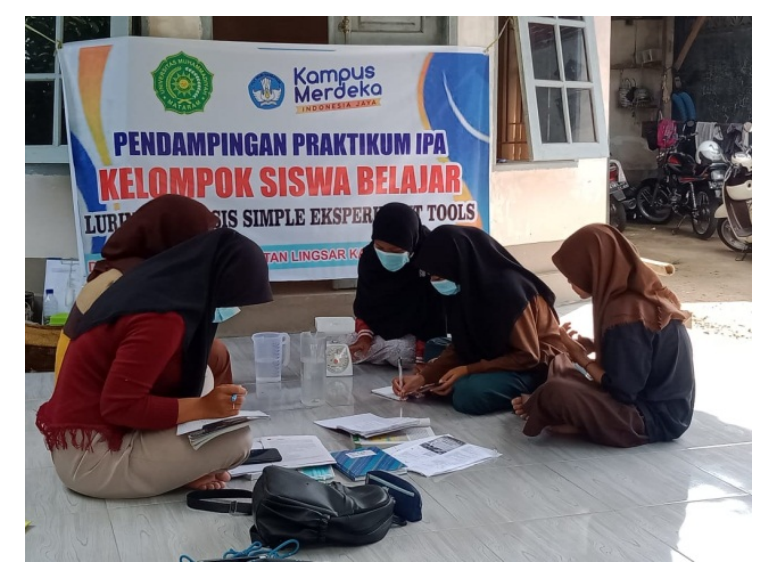

Gambar 2. Kegiatan pendampingan praktikum IPA.

Siswa yang hadir pada saat pendamping hanya 5 orang siswa dikarenakan adanya siswa yang sakit sehingga tidak mengikuti pembelajaran luring. Siswa yang hadir sangat antusias untuk mengikuti kegiatan Praktikum. Dari hasil percakapan dengan siswa, mereka menerangkan bahwa di sekolah mereka selama pandemic tidak pernah melakukan kegiatan praktikum.

Setelah melakukan praktikum dilakukan evaluasi tentang respon siswa terhadap praktikum. Diperoleh persentase sebesar $89 \%$ siswa sangat mengerti dengan kegiatan yang dilakukan.

Kegiatan pembelajaran tidak hanya terbatas pada saat pendampingn, siswa juga bertanya tentang materi pelajaran IPA lainnya yang kurang dipahami melalui bantuan Whatshap. 


\section{SIMPULAN DAN SARAN}

Simpulan dari kegiatan pengabdian ini adalah siswa sangat antusias dengan kegiatan praktikum IPA menggunakan alat-alat sederhana yang mudah mereka peroleh di lingkungan sekitar.

\section{UCAPAN TERIMAKASIH}

Terimakasih kepada LPPM Universitas Muhammadiyah Mataram yang telah memberikan dana stimulus untuk kegiatan pengabdian ini. Terimakasih juga kami ucapka kepada kelompok belajar luring desa gontorann yang telah membantu guna lancarnya kegiatan pengabdian masyarakat ini.

\section{DAFTAR RUJUKAN}

Abdillah Abdillah. 2018. Peningkatan Global Media and Information Literacy Professional Network(GMILPN) MGMP Matematika di NTB. Jurnal Pemberdayaan Masyarakat Berkarakter, Vol. 1 No. 1

Anik Ghufron, Widyastuti Purbani, \& Sri Sumardiningsih. (2007). Panduan: Penelitian dan pengembangan. Yogyakarta: Lembaga Penelitian Universitas Negeri Yogyakarta.

Anwar Khairil dan Utami LS.2018. Eksperimen Efek Foto Listrik Berbasis Simulasi Phet.Jurnal Paedagoria, Vol.4, No.2

Arifin, M. (1995). Pengembangan Program Pengajaran Bidang Studi Kimia. Surabaya: Airlangga University Press.

Borg, W. R. \& Gall, M. D. (1983). Educational research: An introduction (4 th ed). New York: Longman Inc.

Bryce, T.G.K., J. McCall, J. MacGregor, I.J. Robertson, \& R.A.J. Weston. (1990). Techniques for Assesing Process Skills in Practical Science: Teacher's Guide. Oxford: Heinemann Educational Books.

Darmiyati Zuchdi, Zuhdan Kunprasetya, Marzuki, et al. (2010). Pendidikan karakter dengan pendekatan komprehensif. Yogyakarta: UNY Press.

Depdiknas. (2006). Panduan Pengembangan Pembelajaran IPA Terpadu, SMP/MTs. Jakarta: Pusat Kurikulum Balitbang Diknas.

Anonim. (2010). Penguatan metodologi pembelajaran berdasarkan nilai-nilai budaya untuk membentuk daya saing dan karakter bangsa. Jakarta: Depdiknas.

Isnaini,M. 2014. Evaluasi kesiapan guru fisika se-kota mataram dalam kegiatan laboratorium, prosiding: seminar nasional tema" sains dan inovasi pembelajaran berbasis kearifan local. IKIP Mataram.

Kelompok Kerja Tenaga Laboratorium. 2012. Modul Diklat Laboratorium IPA. Semarang: FMIPA Unnes.

Nana Syaodih Sukmadinata. (2007). Metode penelitian pendidikan. Bandung: PT. Remaja Rosdakarya.

Rahman Nanang dan Sekar Utami Linda.2016. Pengembangan Buku Petunjuk Praktikum IPA Terpadu SMP Berbasis Home Materials untuk Pembentukan Karakter Peserta Didik" Jurnal Biota, Vol 9, No.2. UIN Mataram.

RISTEKDIKTI. 2020. Buku Panduan Pelaksanaan Penelitian dan Pengabdian Kepada Masyarakat Edisi XIII Tahun 2018. RISTEKDIKTI. Jakarta

Saifuddin Azwar. (2010). Tes prestasi. Yogyakarta: Pustaka Belajar.

Salirawati, D. (2001). Materi Pelatihan Kepala Laboratorium Kimia bagi Guru-Guru Kimia Kabupaten Kulon Progo. Disampaikan di Laboratorium FMIPA UNY Yogyakarta, 1 Oktober 2011.

Sriyono \& A. Hamid. 2003. "Pemanfaatan Laboratorium dalam Pembelajaran Fisika SMU." Makalah dipresentasikan pada Seminar Nasional Pendidikan MIPA yang diselenggarakan oleh FMIPA Unnes pada tanggal 22 Februari 2003.

Sumintono, B. 2010. "Pengajaran Sains dengan Praktikum Laboratorium: Perspektif dari Guru-guru Sains SMPN di Kota Cimahi”. Jurnal Penelitian Pendidikan, Vol 15, No. 2. 